\title{
The Role of Board Characteristics in Effective Corporate Governance: The Case of Airbus Group
}

\author{
Fotoh Lazarus Elad ${ }^{1}$ \\ Mei Ngan Wong ${ }^{2}$
}

Nko Solange Bongbee ${ }^{3}$

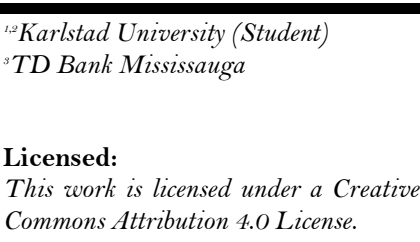

Keywords:

Board characteristics

Board of directors

Effectiveness

Corporate governance.

\begin{abstract}
Recent financial crises, economic collapses, and the fall of giant corporations due to accounting fraud and governance irregularities has brought corporate governance to the limelight especially with regard to the role of the board of directors. The board of directors is charged with monitoring and advising management and likewise providing strategic direction for the corporation. Board characteristics are instrumental towards the effective implementation of corporate governance principles in firms. This study evaluates the influence of board characteristics of; board composition and independence, board size, board diversity, board meetings and committee structure on effective corporate governance practices in Airbus group. This paper adopts a qualitative approach through which secondary data obtained from the corporate governance report of the board of directors for 2015 is analyzed. The findings of the study highlight the significance of key board characteristics features in ensuring effective corporate governance practices. Therefore the implication of this study is for corporations to apply recommended board characteristic features which serve as a catalyst towards effective corporate governance in corporations.
\end{abstract}

\section{Introduction}

Corporate governance has been a hot topic in boardrooms (Subramanian, 2015) the media and among stakeholder groups. Recent financial crises, economic collapses, accounting fraud, and failures have been the main catalyst fuelling the debate and prominence of corporate governance nowadays (Brown \& Caylor, 2006). Most of these corporate collapses involved giant corporations like; Enron, WorldCom, Parmalat, Arthur Andersen, Freddie Mac, HealthSouth and Tyco International. These collapses had adverse effects on share prices, capital markets and investors' confidence as investors lost huge amounts of their investments. The aftermath of these corporate scandals resulted to investors clamouring for enhanced mechanisms to enhance transparency and accountability of corporate executives. As a result, significant attention and pressure have been paid to the role of the board of directors in strengthening corporate governance practices. The monitoring role of the board plays a pivotal role in effective corporate governance which is the main focus of this paper. Board of directors help shareholders and other stakeholders in implementing mechanisms which ensure the interest of shareholders and stakeholders are met. This partly results from the separation of ownership and control functions and the ensuing agency problem which requires the board of directors to efficiently discharge their monitoring duties.

The board of Director plays a crucial role in corporate governance especially with regard to board characteristics such as; composition, size, diversity, committee structure, the frequency of meetings, styles, structure, processes, activities and their relationship. Jan and Sangmi (2016) further highlight the role of the board which encompasses, monitoring the activities of management, assuming an advisory and supportive role and ensuring the overall governance of the company by providing strategic direction to ensure organizational objectives are fulfilled. It is against these fundamental functions of the board that most board of directors is evaluated. The effectiveness of corporate governance is an issue that has been on the tables of many boards and has consequently resulted in the development of internal rules guiding the board of directors in discharging their duties. The aim of such internal regulations most often is to prevent irregularities, scandals, and ensure the smooth governance of corporations. So far, there are a number of corporations which have developed effective corporate governance codes. One of such companies is the Airbus group.

Airbus Group is a global pioneer in aeronautics, space, and defense-related services through its creation of cutting-edge technology (Airbus, 2016). With its headquarters in Leiden, Netherlands, Airbus has over 136,574 employees spread across all its divisions. The board of directors and executive committee manages the Group. The corporate governance system of Airbus ensures the group is managed according to its regulating laws and article of associations, which are updated to meet its growing ambitions, obligations and target goals (Airbus, 2016). Airbus group recorded a massive success in the third quarter of 2016 with a revenue totaling 43 Billion Euros, earnings per share of 2.34 Euros and a share price of 59.38 euros (Airbus, 2016). Airbus 
group is said to be on track by meeting shareholders and stakeholders expectations. Giving the remarkable success Airbus group achieved in 2015, we explore the board characteristics of Airbus group in order to understand how it affects the corporate governance practices of the group.

Thus this paper aims to evaluate the role of board characteristics in ensuring effective corporate governance in Airbus group. In other to accomplish this goal, we propose the following research questions:

Do board characteristics affect the effectiveness of corporate governance practice?

In what ways can board characteristics result in effective corporate governance practices?

In order to answer these questions, we used a qualitative analytical approach in which, secondary data pertaining to the report of the board of directors of Airbus group for 2015 was analyzed and used as the sole data source for this study. This study is significant as it contributes to existing literature by analyzing the role played by board characteristics in ensuring effective corporate governance practices. The remainder of this paper is organized thus; in section 2 we present a literature review on board characteristics components. Thereafter in section 3, the methodology is presented, section 4 contains the results and discussion of the study, meanwhile section 5 concludes with the discussion and recommendation for future studies.

\section{Theoretical Framework}

\subsection{Board Characteristics}

John and Senbet (1998) identify three board characteristic vital in evaluating the effectiveness of a firm's corporate governance and the board which includes; board size, board composition, and independence. The authors further highlight the significance of these characteristics in enhancing board supervision and monitoring in order to guarantee high firm performance. Other scholars like, Fauzi and Locke (2012) underline board diversity as one of those imperative characteristics in evaluating a firm's corporate governance practice and board performance, meanwhile some scholars like, Ntim and Osei (2011) dwell on the frequency of board meetings, whereas others like, Klein (1995) stress the importance of board committee structure on the effectiveness of corporate governance practice in firms.

\subsubsection{Board Composition and Independence}

In focusing on board composition John and Senbet (1998) lays emphasis on board independence and outside directors. Clifford and Evans (1997) define board composition in relation to the number of independent non-executive directors serving on the board compared to the overall number of directors. An independent non-executive director is one who does not occupy any post of responsibility in the firm and has no stakes and affiliation in the firm. Clifford and Evans (1997) further note that boards tend to be more independent with a proportionate increase of outside directors. Furthermore, the effect of board independence through the presence of independent board members has a positive impact on the overall wealth of shareholders and in disciplining corporate executives. In a study carried out by Rosenstein and Wyatt (1990) they found a positive relationship between the appointment of an external board member and shareholder's wealth. Based on this study, the presence of outside board members impacted shareholder's wealth positively. Even though other studies such a Bhagat and Black (2002) found no significant relationship between independent director presence on the board and performance, this could be explained by the inability of the board to operate to full capacity. Furthermore, the agency theory equally lends credibility to the argument in favour of having independent directors on the board. The agency theory emphasizes that, because of the separation between ownership and control, managers tend to pursue their personal aims at the detriment of shareholders (Jensen \& Meckling, 1976). Therefore the independent non-executive board members perform an oversight and monitoring in curbing management's excesses.

\subsubsection{Board Size}

It is generally assumed that large boards bring a wide range of access to expertise and resources and likewise management oversight (Fauzi \& Locke, 2012). In a study, Coles, Daniel, and Naveen (2008) in examining the ideal size of a board classified firms into two categories; complex firms and simple firms. The authors further observe that the size of the board has an impact on its orientation and effectiveness. Complex firms tend to have large boards which often results in higher performance. From an agency point of view, larger boards tend to focus more on the agency problem as many directors are likely to focus on monitoring management's activities. From a resource dependency standpoint, large boards tend to secure more opportunities for the firm resulting in more access to resources. The stewardship viewpoint depends on the proportion of board members who are outside directors. Inside directors bring valuable information important for decision making, meanwhile, outside directors use such information to make decisions which benefits all stakeholders of the firm. Fauzi and Locke (2012) underline the size of the board to be a determining factor affecting firm's performance. The authors further note that there is no acceptable ideal size of a board. In an earlier study, Singh and Harianto (1989) noted that large boards tend to reduce the influence of the CEO on the board by effectively monitoring management activities which had a positive impact on the firm's performance. Pearce and Zahra (1992) see large board sizes as enhancing diversification, while Sanders and Carpenter (1998) emphasize the possibility of internalization as a result of a large board. Hence Randøy, 
Thomsen, and Oxelheim (2006) conclude that such large boards have the potentials of increasing the pool of expert knowledge available to executive management. Furthermore, in another study, Hillman and Dalziel (2003) note that organizations increase the board size in order to enhance resource dependency by maximizing the provision of a firm's resources. Meanwhile, Pfeffer and Salancik (1978) accentuate that, larger boards can easily deal with environmental uncertainties and can easily form links with business partners.

On the other hand, Weisbach (1988) counteracts the argument for large boards by noting that smaller boards are more effective than large boards. Lipton and Lorsch (1992) advance incremental cost, communication and decision making difficulties to be some of the repercussions of having a large board. However, Jensene (1986) instead prefers to highlight the advantages of having a small board which includes; enhanced communication, coordination, and cohesiveness. Other scholars argue that a too small board lack the diversity of opinion and expert advice common in large firms (Dalton \& Dalton, 2005) and smaller boards tend to be preoccupied with decision making and less on monitoring management's activities (Tusiime, Nkundabanyanga, \& Nkote, 2011). In another study, Kathuria and Dash (1999) underscore that the benefit of enhanced monitoring surpasses the loophole coordination, communication and poor decision making. Jensenp (1983) recommends a board size of seven or eight members, Lipton and Lorsch (1992) recommend 10 with a preferable size of eight or nine. Furthermore, the Cadbury report proposes eight to ten members (Cadbury, 1992). The ideal board size based on all these recommendations falls between seven and ten.

\subsubsection{Board Diversity}

In today's corporate setting, gender is the most debated aspect of board diversity (Fauzi and Locke 2012). There have been moves in some European countries likes Norway, Iceland, and Spain to increase the number of women serving on the board. From an agency theory viewpoint, the theoretical literature supports gender diversity for example (Hampel, 1998) underscores the effect of board diversity in ensuring a balanced board with no single individual dominating board decision making. Board diversity plays a vital role in resource dependency by providing additional linkages to resources (Fauzi \& Locke, 2012) such as capital, corporate partners, suppliers and customers (Alexander, Fennell, \& Halpern, 1993) as a result of board diversity which serves various stakeholder needs (Keasey, Thompson, \& Wright, 1997). Board diversity serves as an added value for the firm and positively impacts firm's performance (Huse \& Solberg, 2006). From a gender diversity standard, female directors tend to possess supplementary skills and perspective which male directors do not possess (Fauzi \& Locke, 2012).

Carter, Simkins, and Simpson (2003) in a study of Fortune 1000 firms observed a statistically significant relationship between female and minority directors and organizational performance. In a related study on Fortune 500 firms, Jurkus, Park, and Woodard (2008) observe that gender diversity of top female management is positively related to stock valuation and overall board performance. Similarly,

Bonn (2004) findings provide additional support in favour of board diversity. Greater board diversity has the potentials of enhancing innovation capacity, ensuring a better understanding of diverse customers and enhancing global understanding (Daily \& Dalton, 2003). Having female directors on the board has two principal advantages; female directors usually possess an understanding of customer needs and consumer expectation and likewise, knowledge about the measures firms can take to meet customer expectations (Brennan \& McCafferty, 1997). In another study (Randøy et al., 2006) found no significant relationship between board diversity and firm performance in relation to profitability and stock market valuation. The authors equally noted that, board diversity does not lower firm's performance except in cases where board diversity involves increasing the board size.

\subsubsection{Board Meetings}

There are varying and conflicting viewpoints on the role of board meetings on a firm's performance (Lipton \& Lorsch, 1992). The frequency of board meetings is considered to be of significance in improving board performance and effectiveness (Johl, Kaur, \& Cooper, 2015). There is a viewpoint that the frequency of board meetings has a positive relationship to a firm's corporate financial performance and managerial monitoring (Conger, Finegold, \& Lawler, 1998). The frequency of board meetings keeps directors abreast about vital developments within the firm hence, reducing information asymmetry (Mangena \& Tauringana, 2008) enabling the board in strategy formulation and evaluating management's performance (Vafeas, 1999). This further enables the board to respond promptly to emerging problems facing the firm (Mangena \& Tauringana, 2008). Lipton and Lorsch (1992) further contend that informal interactions during such frequent board meetings further strengthens the cohesiveness within the board. During a financial crisis, firms with a poor meeting attendance significantly underperform compared to firms with good performance (Francis, Hasan, \& Wu, 2015). In a related study, conducted in South Africa, Ntim and Osei (2011) observed a significant positive relationship between the frequency of board meetings and the firm's financial performance. Other studies counteract this position, for example, a study by Vafeas (1999) found that frequent board meetings increases travel expenses, wastage of managerial time and let to an increase in director meeting expenses. Directors in most cases during such board meetings do not have the time to ask relevant questions as most of the time is used to present reports. 
Nevertheless, Ntim and Osei (2011) conclusion support the agency theory, which purports that corporate boards which meet more frequently can effectively monitor, advise and control management which has the effect of increasing the firm's financial performance and efficiency. Furthermore the authors argue that, previous studies which downplay the importance on the frequency of board meetings on firm's performance and efficiency employed a flawed methodological approach with most using the ordinary least square regression. Jensens (1993) strikes a balance by proposing that, rather than having frequent board meetings, the board should be responsive to the challenges facing the firm. During such circumstances, frequent board meetings can be held to address the crisis. Jensens (1993) further proposes other circumstances appropriate for frequent board meetings which include; when the interests of shareholders are at stake, when the firm is fighting a hostile takeover and when the CEO is to be replaced. Vafeas (1999) supports this position by noting that, firms which are able to strike the appropriate balance of the number of board meetings enjoy economies of scale.

\subsubsection{Committee Structure}

The internal administrative structure of the board plays an important role towards board effectiveness and corporate governance practices. In a study, Klein (1995) evaluated the impact of board committee structures and the director's role in the efficiency of the board. The author further recommends a committee structure with highly specialized roles which enhances the productivity and monitoring role of the board. Klein (1995) further proposes that each committee should be composed of competent staffs with the objectives of each board committee geared towards fulfilling the productivity or monitoring objectives of the firm. The most common committees in companies include; finance, strategy, investment, audit, compensation and nomination committees (John \& Senbet, 1998). John and Senbet (1998) underline that committees which are productivity oriented (finance, strategic and investment issues) are usually composed of insiders, whereas committees which fulfill a monitoring role (audit, compensation, and nomination) are usually composed of an external independent director. The authors observed a positive relationship between outside directors serving on monitoring committees and performance measures linked to the benefits of monitoring such as the firm's free cash flow and outstanding debt. John and Senbet (1998) equally observed a positive relationship between the proportion of insiders serving on productivity committees and performance measures connected to a firm's productivity such as returns on stock markets, net income, and capital expenditure productivity.

\section{Methodology}

This study adopts a qualitative analytical perspective with an interpretivism epistemological approach in which we analyzed the role of board characteristics on corporate governance of Airbus group. By adopting the interpretivism perspective, we adopted the inductive research approach. Our choice of the qualitative research approach is justified by the explanation of Bryman and Bell (2015) who underscore that the qualitative approach forms an important link between the theoretical perspective and the study in order to gain an enhanced understanding and knowledge about the case study. Furthermore, this approach enables us to gain a holistic view and deeper understanding of the case study. Based on our research question, we applied a research design format which facilitated data collection, measurement, and analysis. The most suitable research design for this study was the case study research design. The case study has the advantage of enhancing understanding as to why observed phenomenon happens in a particular way (Yin, 2009) and likewise forms a reliable interpretation of reality (Gagnon, 2010). Case studies are often used to generate a theory or describe a pattern or a phenomenon (Ghauri \& Grønhaug, 2010).

Since this study focuses on evaluating the impact of board characteristics on the effectiveness of corporate governance of Airbus group, we adopted an exploratory in-depth approach of the corporate governance report of the board of directors for the 2015 fiscal year. This enabled us to gain an enhanced understanding of the role of board characteristics towards effective corporate governance of Airbus group. Secondary data obtained from the report of the board of directors of Airbus group for 2015 was used as the main data source for this study. We used the Karlstad University search engine to obtain relevant literature from Science Direct, Business Source Premier, Emerald, Ebrary and Sage Premier to build the theoretical foundation of this study and business research methods books were used to choose a suitable methodology. Finally, the corporate governance report of the board of directors for Airbus Group for the fiscal year 2015, obtained from Airbus website was used for the discussion and analysis section of this study.

In this study, we used the data analytical and interpretive procedures highlighted by Ghauri and Grønhaug (2010). Considering the huge amount of data collected, we used the data reduction procedure of Collis and Hussey (2014) through which we selected, simplified and summarized data relevant for this study while discarding data not needed. Furthermore, we used the content analysis procedure for labeling, coding and analyzing data. The theory-guided analysis approach enabled us to constantly compare theoretical literature with data collected from the annual corporate governance report of Airbus group for 2015. We equally employed the textual analytical technique to gain a deeper and enhanced understanding as to how board characteristics affected the corporate governance practices of Airbus group. Prior knowledge about 
corporate governance and board characteristics contributed to shaping our interpretation even though the theoretical framework formed the basis of our analysis.

The scope of this study is limited to secondary data obtained from the corporate governance report of the board of directors which represented just the directors' perspective. It was our wish to conduct in-depth interviews with employees, the management, shareholders and other important stakeholders of Airbus group to get their perspective. Time constraint prevented us from achieving this goal. The study principally used secondary data obtained from the website of Airbus Group. We trust the information obtained from Airbus group's website to be reliable, complete and present accurately the corporate activities of the board and the group because of the group's commitment to the integrity of reporting their activities. Furthermore, the theoretical literature which served as the basis of our analysis were mainly peer-reviewed articles obtained from reliable sources.

\section{Results and Discussion}

\subsection{Board Characteristics}

\subsubsection{Board Size, Independence, and Composition}

The report of the board of directors for 2015 states that according to the Articles of Association, Airbus can at most have 12 members as Board of Directors with a term limit of three years. This number is higher than the seven to ten range suggested by some scholars (Cadbury, 1992; Jensenp, 1983; Lipton \& Lorsch, 1992). Yet, there is no generally accepted ideal size of a board of directors (Fauzi \& Locke, 2012). The size of the board should consider the structure of a company - if it is complex or simple (Coles et al., 2008). In the case of Airbus, it is a multinational company which for sure is a complex company. Although the board size of Airbus exceeds the recommendations by some scholars, due to its complexity, it may be acceptable for Airbus to have a slightly larger board size.

The large board size of Airbus has the potentials of enhancing more diverse expertise, improving resource dependency and bettering management monitoring activities to improve the overall company performance (Fauzi \& Locke, 2012; Hillman \& Dalziel, 2003; Singh \& Harianto, 1989). Besides, the large board size of Airbus can improve coordination and communication (Jensenp, 1983) within the firm. However, a large board size also comes with disadvantages. A large board size in Airbus may at the same time increase the incremental cost and difficulties in decision making as a group (Lipton \& Lorsch, 1992). Yet, with focus on corporate governance and management overview perspectives, the board size in Airbus suggests that the board is effective in monitoring management to improve the Company's performance.

The Articles of Association further requires that the board be made up of one executive director and eleven non-executive directors. Furthermore, the Chief Executive Officer (CEO) of Airbus is appointed by the board of directors and is expected to be an executive director and an EU resident and national. In order words, the shareholders appoint an individual as an executive director, and the board of director appoints him/her as CEO. Therefore, including the Chairman of the board of directors, in total there should be at least nine nonexecutive directors on the board of directors of Airbus Group (Airbus, 2016). But so far, there are 12 members in its board of directors, including its CEO and Chairman with 9 members being independent and 1 member being non-independent (Airbus, 2016) which surpasses the threshold of 9 as stated in the Articles of Association in Airbus.

It is important to identify the independent non-executive directors from insiders to evaluate the board independence (John \& Senbet, 1998) of Airbus. In Airbus, 10 out of 12 members (around 83.33\%) of the board of directors are independent directors. The high proportion of independent board members serving on Airbus has resulted to a highly independent board, thus guaranteeing growth and improvement of shareholders' wealth and the monitoring of management's activities (Clifford \& Evans, 1997; Rosenstein \& Wyatt, 1990). Many companies, including Airbus, have an agency problem due to the separation of ownership and control. Although management has the responsibility to safeguard the interests of shareholders, it is possible for them to put their personal goals and interests over those of shareholders (Jensen \& Meckling, 1976).

Additionally, the board of directors through majority votes recommends individuals to the Shareholder's meeting to be appointed as director (Airbus, 2016). Shareholders of Airbus group are forbidden to nominate an individual for directorship. This rule has the potential of ensuring that, qualified candidates are appointed to the board based on their skills and not through lobbying by shareholder groups. In many corporations, shareholders can lobby to have a compromising candidate on the board who promises to fulfill particular shareholders' demands. This rule prevents such from happening, thus resulting in the application of better corporate governance practices.

\subsubsection{Board Diversity}

The board of directors is required to assist Airbus group in accomplishing its targets and goals (Airbus, 2016). Therefore, Airbus requires every board member to meet the required qualification, knowledge, skills, and experience to discharge their roles and responsibilities as board members. Airbus equally supports the argument that, greater board diversity in terms of; nationality, experience and others can result in higher efficiency and better quality value on the board. The higher resource dependency of Airbus group can be 
explained by its diverse board which serves various stakeholders need which is supported by a study conducted by Fauzi and Locke (2012).

With regard to gender diversity, Airbus (2016) is in the process of implementing the guideline on the gender composition of the board of directors which requires at least $30 \%$ men and $30 \%$ women on the board. This guideline is based on a Dutch draft bill. In 2015, there were 2 women on the board out of the 12 members representing $16.17 \%$ of the board. The Company realized the need for further improvement for gender diversity and agreed on introducing one more female member in the board to increase the proportion of women on the board to $25 \%$ (i.e. 3 members).

Although Airbus still has not met the guideline of the minimum board composition rate of at least $30 \%$ of women on the board, the situation may change as more female directors fill in director positions. Airbus is already putting in place measures to increase the number of women on its board. The gender diversity of the board is said to enhance the resources dependency and performance capacity (Fauzi \& Locke, 2012; Huse \& Solberg, 2006) of Airbus. Moreover, the increase in the number of female directors can also add value to Airbus by providing supplementary skills and perspectives differed from those of male directors (Fauzi \& Locke, 2012). Airbus is a service-oriented company, so it is important for Airbus to understand the needs and expectations of its customers. Female directors are often said to better possess these understanding and knowledge to meet these requirements better than male directors (Brennan \& McCafferty, 1997).

Furthermore, the competency skills of directors of Airbus is diverse with all 12 members having expertise in global industry business, 9 in manufacturing and production, 8 in engineering and technology, 7 in aerospace industry, 6 in geopolitical economics, 5 in defense industry, 3 in information and data management and 1 in Asia (Airbus, 2016). After the board review in 2015, the board of directors agreed to strengthen the selection of new board members based on board skills matrix.

The diversity of skills of the board of Airbus creates a competitive advantage and market position for Airbus group in general. It equally enables Airbus group to continue improving its R\&D. The high level of board diversity in Airbus can contribute to an increase in innovation capacity and a better understanding of various customers and markets globally (Daily \& Dalton, 2003). Even though Airbus has a lot to do concerning the gender diversity of its board, the board of director maintains a degree of diversity of skills which is a contributing factor to the success of the company. It is reasonable to believe Airbus enjoys the benefits of board diversity which impacts its corporate governance practices.

\subsubsection{Board Meetings}

During the financial year 2015, there were 9 board of directors meetings with the average attendance rate of $91 \%$ and 7 meetings with $88 \%$ average attendance rate in 2014 Airbus (2016). Business reports from the $\mathrm{CEO}$ are used to inform the board regularly about business developments such as; operation and strategic plans. Regarding the committee meeting within the board, the audit committee is required to have at least 4 meetings per year and the remuneration, nomination and governance committee are expected to have at least 2 meetings a year Airbus (2016). In 2015, the audit committee and remuneration, nomination and governance committee had 5 meetings with $80 \%$ average attendance rate and 6 meetings with $96 \%$ average attendance rate respectively Airbus (2016).

The board meeting frequency and average attendance rate increased in 2015 compared to 2014. Furthermore, both the audit committee and the remuneration, nomination and governance committee had more meetings in 2015 which exceeded the minimum guideline. The frequency of meetings and attendance keeps the board abreast and updated about developments within the company, and equally enables the board in strategy formulation and evaluating management's performance on a timely manner (Mangena \& Tauringana, 2008; Vafeas, 1999). Moreover, the frequent board meetings in Airbus provide an opportunity for directors to strengthen the cohesiveness with each other (Lipton \& Lorsch, 1992). This can improve the financial performance and business efficiency (Ntim \& Osei, 2011) of Airbus. Therefore, the frequency of board meetings in Airbus is a contributing factor to the efficiency and effectiveness of the board and its corporate governance practices. However, Airbus needs to always make an evaluation of the cost-benefit analysis in order to avoid the downside of frequent meetings. Too frequent meetings can have an adverse effect on the company leading to an increase in travel expense and director expense, workload of directors and management, and wastage of managerial time (Vafeas, 1999).

\subsubsection{Committee Structure}

Airbus (2016) principally has two board committee groups; the audit committee and the remuneration, nomination and governance committee. The audit committee is responsible for the annual financial statements, interim accounts and internal and external audit issues. On the other hand, the remuneration, nomination and governance committee is responsible for consulting with the $\mathrm{CEO}$ and making recommendations about appointment issues and contractual matters. This is in line with the recommendation of John and Senbet (1998) who proposes that committees which are productivity oriented should have insiders as committees, which explains why the CEO of Airbus is consulted in contractual matters and appointments. Furthermore, the highly specialized roles of committees have the consequence of enhancing the productivity of Airbus and 
facilitating the board's monitoring role (Klein, 1995). Additionally, the best candidate for the job guideline for appointment further ensures the committee members are suitable and capable of their jobs (Klein, 1995). Moreover, both committees are responsible for monitoring and evaluating management's performance. By having only external independent directors on its board committees, Airbus can benefit from better monitoring (John \& Senbet, 1998).

Therefore, the board committee structure is favorable in increasing the efficiency and effectiveness of the board of director in Airbus as a whole.

The governance aspect was first included in the committee after the board evaluation of 2014. According to the guideline principle related to management appointment in Airbus, it stresses that the best candidate should be assigned to the job or position.

Both audit committee and remuneration, nomination and governance committee is made up of four members each with all members being independent directors.

\section{Conclusion}

Corporate governance is an important agenda in many organizations nowadays. It is especially important for the board of directors of a company to be effective and efficient in order to contribute to the corporate governance development of a company.

Several scholars have identified several aspects of board characteristics which could impact corporate governance positively. In this paper, we developed a comprehensive analysis of the impact board characteristics have on the practice of corporate governance in Airbus group.

Based on the analysis of key board characteristics including; board composition and independence, board size, board diversity, board meeting frequency and board committee structure, we conclude that board characteristics play an important role in effective corporate governance.

With regard to the board structure, Airbus has a reasonable board size with a high percentage of independent directors on its board, high board diversity in expertise and medium diversity in terms of gender, frequent board meetings and well-defined board committees with best candidates.

Finally, the board has been actively participating in strategic decision making as well as monitoring the actions of management. All these measures indicate the effective significance board characteristics play in effective corporate governance especially when applied adequately. Board characteristics enhance the effectiveness and efficiency of the board which consequently result in a high company performance.

Given the important role of board characteristics on corporate governance, it is essential for companies to adopt a comprehensive measure to utilize board characteristics to strengthen the corporate governance practice within companies.

This paper is, therefore, beneficial and useful for companies, investors and major stakeholders in evaluating the impact of board characteristics on the efficiency and effectiveness of corporate governance. Through an in-depth analysis of the board characteristics, companies can identify the strengths and weaknesses of its board in relation to corporate governance and company performance.

In this study, the evaluation of board characteristics on the effectiveness of corporate governance of Airbus is based on secondary data from the annual report of the board of directors for 2015.

Some detailed information about its board of directors is not comprehensive or accessible to facilitate the analysis. Therefore, a similar study could be done in the future which encompasses both primary and secondary data in order to get a holistic perspective on the subject.

Additionally, this paper mainly focuses on the role of board characteristics on the effectiveness of corporate governance. Future research could focus on these areas to develop a more scientific causal relationship between board efficiency, corporate governance, and company performance.

\section{References}

Airbus. (2016). Report of the board of c directors. Retrieved from
https://www.airbusgroup.com/dam/assets/airbusgroup/int/en/investorrelations/documents/2016/GeneralMeeting/Report-of-the-Board-of-Directors-2015-Airbus-Group-SE/Report\%200f\%20the\%20Board\%20of\%20Directors\%202015\%20Airbus\%20Group\%20SE\%20.pdf [Accessed 2016-12-14].

Alexander, J. A., Fennell, M. L., \& Halpern, M. T. (1993). Leadership instability in hospitals: The influence of board-CEO relations and organizational growth and decline. Administrative Science Quarterly, 38(3), 74-99.

Bhagat, S., \& Black, B. (2002). The non-correlation between board independence and long term firm performance. Journal of Corporation Law, 27, 231-274.

Bonn, I. (2004). Board structure and firm performance: Evidence from Australia. Journal of the Australian and New Zeal and Academy of Management, $10(1), 14-24$.

Brennan, N., \& McCafferty, J. (1997). Corporate governance practices in Irish companies. Journal of Irish Business and Administrative Research, 18(1), 116-135.

Brown, L., \& Caylor, M. (2006). Corporate governance and firm valuation. Journal of Accounting and Public Policy, 25(4), 409-434.

Bryman, A., \& Bell, E. (2015). Business research methods (4th ed.). New York: United States of America. Oxford University Press. 
Cadbury, R. (1992). The report of the committee on the financial aspects of corporate governance, published by the financial reporting council of the London stock exchange, United Kingdom. Retrieved from http://www.ecgi.org/codes/documents/cadbury.pdf [Accessed 2016-12-09].

Carter, D. A., Simkins, B. J., \& Simpson, W. G. (2003). Corporate governance, board diversity, and firm value. Financial Revierw, 38(1), 33-53.

Clifford, P., \& Evans, R. (1997). Non-executive directors: A question of independence. Corporate Governance, an International Review, 5(4), 224-231.

Coles, J. L., Daniel, N. D., \& Naveen, L. (2008). Boards: Does one size fit all? Journal of Financial Economics, 87(2), 329-356.

Collis, J., \& Hussey, R. (2014). Business research: A practical guide for undergraduate and postgraduate students (4th ed.). New York: Palgrave Macmillan.

Conger, J. A., Finegold, D., \& Lawler, E. E. (1998). Appraising boardroom performance. Harvard Business Review, 76(1), 136-148.

Daily, C. M., \& Dalton, D. R. (2003). Women in the boardroom: A business imperative. Journal of Business Strategy, 24(5), 89 .

Dalton, C. M., \& Dalton, D. (2005). Boards of directors: Utilizing empirical evidence in developing practical prescriptions. British Journal of Management, 16(1), S91 - S97.

Fauzi, F., \& Locke, S. (2012). Board structure, ownership structure and firm performance: A study of New Zealand listedfirms. Asian Academy of Management Journal of Accounting and Finance, 8(2), 43-67.

Francis, B., Hasan, I., \& Wu, Q. (2015). Professors in the boardroom and their impact on corporate governance and firm performance. Financial Management, $44(3), 547-581$.

Gagnon, Y.-C. (2010). The case study as research method: A practical handbook. Quebec, Canada: The Presses of the University of Quebec.

Ghauri, P., \& Grønhaug, K. (2010). Research methods in business studies (pp. 4). Harlow, England: Pearson Education Limited.

Hampel, R. (1998). Committee on corporate governance: Final Report. London: Gee Publishing Ltd.

Hillman, A. J., \& Dalziel, T. (2003). Boards of directors and firm performance: Integrating agency and resource dependency perspectives. Academy of Management Revierw, 28(3), 383-396.

Huse, M., \& Solberg, A. (2006). Gender-related boardroom dynamics: How Scandinavian women make and can make contributions on corporate boards. Women in Management Review, 21(2), 113-130.

Jan, S., \& Sangmi, M. (2016). The role of board of directors in corporate governance. Imperial Journal of Interdisciplinary Research, 2(5), 707-715.

Jensen, M. C., \& Meckling, W. H. (1976). Theory of the firm: Managerial behavior, agency costs and ownership structure. Journal of Financial Economics, 3(4), 305-360.

Jensene, M. C. (1986). Agency costs of free cash flow, corporate finance, and takeovers. American Economic Review, 76(2), 323-329.

Jensenp, M. C. (1983). Organisation theory and methodology. Accounting Revierw, 58(2), 319-339.

Jensens, M. C. (1993). The modern industrial revolution, exit, and the failure of internal control systems. Journal of Finance, 48(3), 831-880.

Johl, S. K., Kaur, S., \& Cooper, B. J. (2015). Board characteristics and firm performance: Evidence from Malaysian public listed firms. Journal of Economics, Business and Management, 3(2), 239-243.

John, K., \& Senbet, L. W. (1998). Corporate governance and board effectiveness. Journal of Banking \& Finance, 22(4), 371403.

Jurkus, A. F., Park, J. C., \& Woodard, L. S. (2008). Gender diversity, firm performance, and environment. SSRN Working Paper, 28 February.

Kathuria, V., \& Dash, S. (1999). Board size and corporate financial performance: An investigation. Vikalpa, 24(3), 11-17.

Keasey, K., Thompson, R. S., \& Wright, M. (1997). Corporate governance: Economic, management and financial issues. Oxford: Oxford University Press.

Klein, A. (1995). An examination of board committee structures. Working paper. New York: New York University.

Lipton, M., \& Lorsch, J. (1992). A modest proposal for improved corporate governance. Business Laweyer, 59(1), 59-77.

Mangena, M., \& Tauringana, V. (2008). Corporate boards, ownership structure and Firm performance in an environment of severe political and economic uncertainty. Paper presented at the British Accounting Association Conference, April 2008, Blackpool.

Ntim, C. G., \& Osei, K. A. (2011). The impact of corporate board meetings on corporate performance in South Africa. African Review of Economics and Finance, 2(2), 83-103.

Pearce, J. A., \& Zahra, S. A. (1992). Board composition from a strategic contingency perspective. Journal of Management Studies, 29(4), 411-438.

Pfeffer, J., \& Salancik, G. R. (1978). The external control of organizations: A resource dependence perspective. New York: Harper \& Row.

Randøy, T., Thomsen, S., \& Oxelheim, L. (2006). A nordic perspective on corporate board diversity. Working Paper. Nordic Innovation Centre, Oslo.

Rosenstein, S., \& Wyatt, J. G. (1990). Outside directors, board independence, and shareholder wealth. Journal of Financial Economics, 26(2), 175-191.

Sanders, W. G., \& Carpenter, M. A. (1998). Internationalization and firm governance: The roles of CEO compensation, top team composition, and board structure. Academy of Management Journal, 41(2), 158-178.

Singh, H., \& Harianto, F. (1989). Management-board relations, takeover risk, and the adoption of golden parachutes. Academy of Management Journal, 32(1), 7-24.

Subramanian, G. (2015). Corporate governance 2.0. Harvard Business Revierw, 93(3), 96-105. 
Tusiime, I., Nkundabanyanga, S. K., \& Nkote, I. N. (2011). Corporate governance: Ownership structure, board structure and performance of public sector entities. Journal of Public Administration and Policy Research, 3(9), 250-260.

Vafeas, N. (1999). Board meeting frequency and firm performance. Journal of Financial Economics, 53(1), 113-142.

Weisbach, M. (1988). Outside directors and CEO turnover. Journal of Financial Economics, 20(C), 431-460.

Yin, R. K. (2009). Case study research: Design and methods (4th ed.). London: Sage. 